\title{
'The central focus of my life': Roselands and Youth Culture in the 1960s
}

\author{
MATTHEW BAILEY
}

$\mathrm{T}$

There is a considerable body of literature both in Australia and internationally that explores the experiences of young people in shopping centre environments. One of the major trends in this literature is the examination of the ways in which young people are excluded from or regulated within privatised public spaces. ${ }^{1}$ Implicit, or briefly acknowledged in these important contributions to debates about the nature of public space, is the desire of young people to spend time and socialise in shopping centre environments. ${ }^{2}$ Fewer studies, though, have examined in depth the nature of this attraction to the mall, particularly in an historical context. ${ }^{3}$ Kowinski's journalistic Malling of America is perhaps the best international example of an investigation of the appeal of the mall environment and its usage as a public space embraced by youth, but in Australia there is little documented evidence to draw upon. ${ }^{4}$

Sydney Journal

Vol 4, No 1 (2013): 112-126

ISBN: 1835-0151

(c) UTSePress and the author 
This article begins to redress this gap in the scholarship, suggesting in the process that more weight be given to the cultural significance of the shopping centre in post-war Australian history. ${ }^{5}$ It examines the development of Roselands shopping centre in the early 1960s and, using written testimony collected through an online survey, young people's experiences of the complex in the second half of the decade. ${ }^{6}$ Roselands opened in the municipality of Canterbury in 1965 as the largest shopping centre in the country. It is important because of its scale, the media attention it received and, perhaps resulting from this, the fact that many people claim it to be Sydney's first major pre-planned suburban shopping centre. ${ }^{7}$ Usage and attitudes towards it are also broadly reflective of the social and cultural positioning of other 1960s retail centres, albeit with some local variation. These centres remain important to people who experienced them because of their place in the story of the city, as well as in personal life narratives. ${ }^{8}$

In his influential The Architecture of the City, Aldo Rossi argued that the succession of events that create the city also constitute its memory the topology of the city is its memory forms. ${ }^{9}$ With his concern for local and unique identifying features, ${ }^{10}$ the globalised urban form of the shopping centre is probably the antithesis of the type of structure he saw as receptacle for cultural identity. Indeed, a wide range of thinkers have argued that a breakdown of collective memory has occurred with the transformation of the traditional city through either trauma or the kind of economic change that mall development marked. ${ }^{11}$ But malls, as this article shows, do contain memories. If these are not as culturally unique as the sense of place pictured by Rossi, an echo still softly sounds for those who experienced formative or socially significant relationships within them, and amongst those who recall the sense of change they ushered in. Frank Mort argues that there is 'strong evidence to suggest that consumers themselves do not view their participation in the marketplace as an isolated activity. The rituals of shopping [for example]... collide with and partly take their meanings from other fields of social action - especially at the level of everyday life. ${ }^{12}$ For respondents in this study, activities in Roselands interplayed with their broader life experience, and the centre became a site in which pivotal memories were emplaced.

\section{BUILDING ROSELANDS}

The development of Roselands was instigated and driven by the Grace Bros department store that, along with a select few other department store family businesses, played a key role in the development of 
suburban shopping centres in Australia. Faced with declining inner city retail sales, and rapidly growing suburban consumption by an affluent, decentralising population, these stores looked to shopping centre development as a method of branch expansion. Myer played a key role in Melbourne, beginning with Chadstone, which opened in $1960 .{ }^{13} \mathrm{In}$ Sydney, Benjamins, a department store until then based in Chatswood, built Top Ryde; Farmers built Miranda Fair; and David Jones anchored Warringah Mall. Having embarked on an early foray into the suburbs in the 1930s at Bondi Junction and Parramatta, ${ }^{14}$ Grace Bros embraced the shopping centre model initially with a homemaker's store at Warringah Mall and then with its own project, Roselands, which outshone all preceding it.

Grace Bros had been eyeing Canterbury since the late 1950s. The area had become an important centre for light industry due to cheap, easy to build on land; good road and rail infrastructure; a rapidly growing population; and favourable rezoning policies by the local council. ${ }^{15}$ Looking to tap into this sound base of strong population and employment growth, Grace Bros scoured maps for a suitable site. After little success, a flight over the area in a small aircraft was arranged. From high above, the uninterrupted green expanse of the Roselands golf course jumped out as 'the perfect answer'. ${ }^{16}$ Its owner, Stan Evan Parry, had been the municipality's Mayor from 1932 to 1947 and was, according to one commentator, 'for nearly half a century perhaps the most powerful and controversial figure in Canterbury'. He had bought the land, the former Fenwick estate, in 1943 and set it up as a golf course before being forced to flee abroad from a Royal Commission into land speculation in $1947 .{ }^{17}$ When he returned in the 1950s, ten years of successively rising land values on the one hand, and the expense of rates and taxes on the other, provided Parry with a compelling motivation to sell, allowing Grace Bros to acquire thirty-one acres in $1958 .^{18}$

Roselands was situated near the intersection of King Georges Road and Canterbury Road. It was about 10 miles from Sydney, and less than five miles from the major population and retail centres of Bankstown, Campsie and Hurstville. ${ }^{19}$ An estimated 714,000 people - around a third of Sydney's population - lived within a twenty-minute drive, while 250,000 could travel to the centre in ten minutes or less. It was within walking distance for 67,000 local residents. ${ }^{20}$ Roselands was also well serviced by public transport: three railway stations - Wiley Park, Beverley Hills, and Narwee - were close by and bus services in the district were expanded to incorporate the new shopping metropolis. ${ }^{21}$ Industry estimates suggested that up to 300 buses arrived and departed daily from the Roselands' terminal carrying around 14,000 people. For 
those arriving by car, a courtesy bus toured the car park, offering a doorto-door ride to the shops. ${ }^{22}$

When Roselands opened, newspapers celebrated 'the largest, most advanced Shopping-Community Centre in the Southern Hemisphere'. ${ }^{23}$ Opening the centre to a packed throng in its centre court, NSW Premier Bob Askin declared that Roselands' 'million dollar spread of merchandise... brings the city to the suburbs in a glittering way that must rival even the fabled Persian Bazaars' ${ }^{24}$ While extravagant, his claim indicated the promise of the shopping centre - it provided almost everything offered by city retail in a secure, cohesively designed form, within easy reach of suburban residents. The scale of development in a suburban environment was unmatched by anything that had gone before it in Sydney. ${ }^{25}$ Even as they acknowledged themselves as beneficiaries of American know-how, Grace Bros executives noted that American shopping centre experts had shown considerable interest in their new centre. ${ }^{26}$ The Sydney Morning Herald reported that its compact three-level layout and decked car park improved on 'wasteful' American 'sprawl' ${ }^{27}$ Although clearly promotional, these claims speak to the innovation of Australian retail development. Sydney's dense urban form and topography encouraged adaptation rather than direct duplication of the expansive single-level construction that had occurred in green field development in the United States. ${ }^{28}$

Acknowledgment of the celebrations that greeted the early Sydney shopping centres should not conceal the extent of retail development that then existed in the suburbs. In 1962, Terrence W. Beed compiled detailed figures on retail floor space for each of Sydney suburbs. Canterbury itself ranked 85 in Beed's list, ordered by size, with just 36,675 square feet of retail. Grocery and food outlets accounted for more than a third of this, with just 3275 square feet devoted to clothing, drapery, soft furnishings and footwear. There was, however, considerable development in nearby suburbs. Bankstown was the second largest suburban centre behind Parramatta with 443,757 square feet of retailing - over 100,000 square feet was used by grocery and food stores and almost 50,000 by clothing, drapery, soft furnishings and footwear stores. Campsie ranked number six with 174,985 square feet of retail floor space, Hurstville tenth with 144,695 and Rockdale sixteenth with $115,325 .^{29}$

But even with considerable nearby development, it is clear that Roselands' innovation, scale, construction methods and materials, intimate linkage with the motor car, sophisticated climate control airconditioning, as well as its range of consumer goods and services, 
provided ample evidence of modernity's largely welcomed invasion. Roselands' Grace Bros was the largest suburban department store in Australia. ${ }^{30}$ The interior of the whole centre encompassed some 30 acres of space. ${ }^{31}$ For respondents in this study undertaken for this article, the overwhelming sentiment when recalling early, large-scale shopping centres was that they were 'modern' and 'exciting'. ${ }^{32}$ The mood was reflected in advertising at the time. A woman could 'step into tomorrow' by purchasing of a new pair of shoes. ${ }^{33}$ Roselands' Grace Bros supermarket was labeled the 'supermarket of tomorrow' ${ }^{34}$ More broadly, shoppers were told they stood 'at the dawn of a new way of life'. $^{35}$

While advertising around the last claim described turning shopping from a chore to a pleasure, it also indicates that more than just retail was on offer. The modern pre-planned shopping centre ushered in a new form of urban space that was internalised, privately-controlled and utilised as a public arena by shoppers and members of the community. While shopping centres later became increasingly rationalised to directly commercial outcomes, ${ }^{36}$ Roselands followed at least some of the precepts of Victor Gruen, architect of the fully-internalised modern mall. Gruen had argued for cohesive planning to incorporate a full range of community facilities into his pre-planned retail environments. Years later he lamented his lost battle, ${ }^{37}$ but in the 1960s the idea still held currency, certainly in the pre-development phase, if not always afterwards. $^{38}$

Roselands was not part of the kind of cohesive urban master plan envisaged by Gruen, but it did provide child minding, rest and play areas, outdoor coffee bars and amusement facilities that added social value to the commercial underpinnings of the centre. Statues, greenery and the magnificent raindrop fountain provided a compelling and attractive backdrop. ${ }^{39}$ The fountain was comprised of fifteen miles of clear nylon thread, descending from the ceiling into a pool. Drops of water streamed down the threads giving the impression of indoor rain. ${ }^{40}$ In terms of facilities, the 'Rendezvous Room' provided women shoppers with a 'place to freshen up', a 'hostess to answer queries', telephones, magazines, a powder room, an ironing room - to 'press a dress while you wait for your friends' - and even showers. ${ }^{41}$ The 'Rose Tearoom' was a favourite for wedding receptions. ${ }^{42} \mathrm{~A}$ Post office and banks provided essential services and 'like any city or town', there was a 'Town Hall'. ${ }^{43}$ Situated on the gallery level, it was designed as a venue for club meetings, wedding receptions and parties, although it did cause some confusion amongst residents who took the name literally, believing they could conduct Municipal business at the centre. ${ }^{44}$ This is revealing of the 
fact that Roselands was not a true town centre - George H. Lewis argues that we should consider mall populations as collectives rather than a communities $-{ }^{45}$ but it also shows that at least some people had expectations or a belief that it did or should operate as one.

\section{HANGING OUT IN ROSELANDS}

The huge Grace Bros department store, massive parking station, meticulously presented internal air-conditioned environment, range of specialty stores, supermarkets and services, as well as the community facilities listed above, combined with intensive promotional activity to generate considerable excitement about the development. Roselands impressed - both up close and, imaginatively, from afar. One local remembers 'watching Roselands being built from Arthur Park, Punchbowl in the 1960s.' The park, she writes, 'was a couple of miles away, as the crow flies, but it was the biggest building on the skyline from that perspective. ${ }^{46}$ Ray recalls that 'people seemed to travel there from all over Sydney at least once, to see what the fuss was about' ${ }^{47}$ Stefania writes that: 'It was a big deal as we lived in a rural area of Sydney, and it was a day trip, we packed up lunches, because it was expensive to purchase items such as a coffee or food' ${ }^{48}$ Twelve-year-old Shonagh travelled there by public transport with two friends from Lane Cove:

to have a day out there. It was obviously significant to me because 40 years later I can still remember that I was wearing white corduroy jeans, probably Amco brand, and the most wonderful crimson red long sleeve shirt with pintucks and buttoning down the back. ${ }^{49}$

Roselands, like all early shopping centres, was marketed towards housewives and family consumption, but youth also embraced it as a social site. A distinctive youth identity informed by American popular culture had developed in Australia in the 1950s, with the concept of 'the teenager' as a life stage sitting between childhood and adulthood an associated import. By the 1960s, the 'teen market' was recognised as an important demographic by marketers and retailers who were adopting age-based market segmentation. ${ }^{50}$ Shopping centres were a distribution point for the consumer products and images that defined the teen market, as well as a figurative representation of the cultural economic system that produced them. Shopping centres emerged as the youth demographic was establishing its identity, the two born from shared economic and cultural circumstances. 
While not the shopping centre's dominant demographic, teenagers created spatial meanings of their own, entwined with a variety of activities coloured by broader cultures of consumption. Roselands, like many other centres, was a partially rendered canvas over which personal experience was painted. For one Canterbury teenager, it was 'like a magnet' for local youth: 'the centre of the area'. ${ }^{51}$ For another local, Robert, Roselands became:

the central focus of my life and that of my friends... I remember in primary school playing cricket in the backyard of friends but by 1967 and onward, each afternoon after school and every weekend was spent meeting up within Roselands to 'hang' with the guys of Punchbowl, Belmore and Narwee Boys and the girls of Wiley Park and Beverly Hills Girls... I met my first girl friend [there] and had my first kiss. ${ }^{52}$

Crowds of teenagers would gather on Roselands' third floor to view on the stage below celebrities such as Robert Vaughn from 'The Man from UNCLE' ${ }^{53}$ Johnny Farnham performed 'Sadie the Cleaning Lady' and when Tiny Tim sang 'Tip Toe Through the Tulips', Pauline and her friends 'stood near the stage and pelted him with plastic flowers'. ${ }^{54}$ Ronnie Burns came to Roselands in 1969 to perform his single 'Age of Consent' causing, according to teen music magazine Go-Set, a 'near riot'. Photographs depict screaming, clutching female fans, security guards struggling to hold them back, and Ronnie being dragged off stage (before centre management shouted him lunch in 'the beautiful "Viking" restaurant'). ${ }^{55}$

While the 'riot' caused a bit of excitement, the youth who flocked to see Ronnie Burns, John Farnham and others did not overtly transgress acceptable modes of behavior that had been established with the commercial mainstreaming of youth culture over the previous ten years. ${ }^{56}$ The Burns promotion provided an immersive, performative display of desire, more sentimental than erotic, ${ }^{57}$ that was readily transferrable to the products on display nearby. Shopping centres were thus another channel for mass-market culture: a new and material distribution point for suburban teenagers. ${ }^{58} \mathrm{Ken}$ recalls that prior to Roselands there were no record stores in the surrounding local suburbs, and that the Grace Bros. record bar, as well as another record/tape store just outside the department store entrance 'did great trade'.$^{59}$ Robert credits Roselands with introducing 'fashion to my group... [because] trends were on show that would have been unknown to those outside 
the complex... Gary Darby's surf shop gave me the look I wanted. ${ }^{60}$ His comments echo industry literature, which advised retailers to market products as 'in', claiming that even adolescent boys were 'more style conscious' than ever before, and that 'study after study' had found that young customers looked 'to their favourite store for... fashion guidance'. ${ }^{61}$

The close association of shopping centres with suburban values gave them a sense of respectability and safety for teenagers and young adults. For Lorne, Roseland's was preferred over the local milk bar, which 'gave you a bad name! $!^{62}$ But even so-called delinquent youth had associations with shopping centres, with gangs linking themselves to different centres. At Roselands long haired boys, called 'Hairies' by one survey respondent, 'Surfs' by another, faced off against the 'Sharps' from Bankstown Square who would arrive to intimidate the locals on their home 'turf'. ${ }^{3}$ Sharps were denim-clad and working class, with short hair and a view of male mods, and long-haired males generally, 'as soft and unmanly'. ${ }^{64}$ Onlookers remember the Sharps 'always bashing up... [boys] with long hair'. ${ }^{65}$ Social groupings and tensions that had nothing to do with Roselands itself were brought to the shopping centre because it was a place of congregation. ${ }^{66}$ Further, this example shows that respective shopping centres could be identifiable as 'belonging' to particular groups. Such identity formation around an urban form is not, on reflection, surprising, but it does complicate our picture of shopping centres and the social milieus associated with them.

Some local residents feared the concentration of teenagers that Roselands had brought so close to their homes. One man living adjacent to the centre claimed his property was being used as a getaway point by a 'hooligan element' fleeing security guards. He demanded that a fence be built to protect his home ${ }^{67}$ Other residents complained to Canterbury Council about youths holding night-time car races and noisy parties in and around Roselands. While these alleged racers owned the night, their younger cousins took over the empty complex during weekend days: 'us kids would use Roselands for hide and seek games and just mucking around', wrote Brent: 'the carpark was the best for skateboard riding in the early [to] mid seventies with not a vehicle in sight from Saturday afternoon till Monday mornings' ${ }^{68}$

\section{WORKING IN ROSELANDS}


Beyond the pleasures of socialising and consuming, Roselands also served as an important site of employment - retail was one of the main drivers of employment decentralisation in Australian cities in the early post-war period ${ }^{69}$ The 1960 s housewife was increasingly under pressure to work outside of the home - as well as in it - as the cost of family consumables stretched beyond the reach of a single pay packet. ${ }^{70}$ Suburban employment, as is well documented, offered opportunities for women: local and with its often part-time structure complementary to the demands of family life. Less attention has been paid to youth employment in retail, but with wartime babies and their post-war siblings coming of working age in the 1960s during a booming consumer economy, many young people got their first jobs in shops. ${ }^{71}$ As Robert notes, when Roselands opened, 300 metres from his house, as an eleven or twelve year old, it changed his socialisation patterns. But for his sixteen-year-old sister, 'it was an opportunity to get a job'. ${ }^{72}$

One eighteen-year-old, Lorne, joined her mother who had found work aged in her fifties in the accounts section in Grace Bros at Roselands. Lorne wrote: 'I loved working with my mother, [and] had a great time getting to know people in Grace Bros. ${ }^{73}$ Her husband Ken recalls that Lorne:

worked upstairs in the Credit/Lay buy section... I had a $\$ 10$ credit account. You couldn't spend more than $\$ 10$ and so I would, when at Teachers College, save some money and pay one or two dollars off my account. In my first year of teaching I met her working in the credit section. She offered me a lolly. I was hooked. We were engaged two months later and married four months after that. ${ }^{74}$

They held their reception in what they describe as the 'Rose Room'. This may have been one of three function rooms in the Town Hall section of the centre available for public hire and use. It was possible for groups to self cater here, reducing costs for those such as Ken and Lorne who were operating on a tight budget.

Another respondent, Pauline, joined the display department of Grace Bros at Roselands after finishing art school as a teenager in the mid-to-late-sixties. She recalls that it was an unusual occupation for a girl at the time, with most of her workmates male and gay:

I loved it and them, they treated me like a favoured child teaching me everything they knew from the 'hey day' of window dressing... at Mark Foys in Sydney. They... 
introduced me to a lot of things, 'completing' my education with ballet, films, food and fashion. I can remember going to see Elvira Madigan with 'Tilly' after he had taken me to the original Adam's Marble Bar. ${ }^{75}$

Watching the ill-fated and tragic love affair of tightrope-walker Hedvig Jensen and Swedish cavalry officer Count Sixten Sparre, they 'sat and held hands and cried throughout the movie. ${ }^{76}$

Pauline also worked on her boss's drag outfits. Echoing Garry Wotherspoon's observation that queens in the 1960s could be seen arriving at the Trocadero Ballroom in George Street, Sydney, in removal vans to preserve their elaborate gowns and wigs, she recalls helping to transport her boss into the city - flat on his back in a station wagon past a flabbergasted toll-collector on the Harbour Bridge. ${ }^{77}$ She had earlier sewn him into a ball gown, which was covered in thousands of tiny mirrors, making it impossible for him to bend at the waist into a regular car seat. ${ }^{78}$ Roselands' claim of bringing the city to the suburbs referred to the range and sophistication of retail, a sense of excitement, the bustle of a marketplace, and so on. But for Pauline, the city that came to Canterbury was not material but cultural and personal. It came in the form of introductions to a wider world. Rather than limiting her journeys to the local, the shopping centre, through the urban experience and generosity of her workmates, encouraged her to travel further, to look beyond her surrounds, to embrace rather than eschew the city.

\section{CONCLUSION}

Roselands was instrumentally conceived and designed, ${ }^{79}$ and was an early pillar in Grace Bros' master plan to 'encircle the city' ${ }^{80}$ But it also served as an important social site for young people in the area. When Lorne reprised her memories of Roselands she was surprised at what she found, not in terms of the environment itself, but in her feelings about it and the links it held with her life at the time:

I thought I would be really critical of the shopping centre, like mass consumerism, capitalism gone mad etc but really I have fond memories of Roselands... it's been really lovely being prodded to reminisce about this time in my life and I'm really glad I have reconnected with those memories.

Shopping centres arrived in Australia as the post-war boom gathered momentum. They represented its strengths and possibilities and 
symbolised the entry of modernity on a mass-scale to suburban areas. Roselands has been marked for special attention, then and since, for its significance in this broad story, and the statement it made in Sydney's built form at the time. For the young it felt new, and in the 1960s many teenagers celebrated it for the world it brought to their doorsteps. A huge and glorified material space, it facilitated consumption of the images and products of global capitalism. Its spatiality was shaped by self-identification with these creations as well as through networks of personal relationships, social activity and, no doubt, youthful enthusiasm. This is not to deny the rationalist design of the shopping environment, nor teenagers' awareness of it, but to recognise that there is more to the story.

Drawing on Katz's concept of 'ecologies of youth', Vanderbeck and Johnson have argued that young people in the United States have actively used malls to fulfill personal developmental needs - 'to be stimulated, act autonomously, explore, [and] socialize' ${ }^{81}$ Interpreting the space of the mall as a personalised social field informed by popular culture and practices of consumption, Canterbury youth created a place of meaning and belonging in Roselands, which for some still reverberates with the voices of their past. Understanding this allows us to see Roselands as one of the city's memory forms, preserving traces of emplaced experience linked to both personal lifestages and a dynamic period in Sydney's recent history.

Matthew Bailey is Lecturer in the Department of Modern History at Macquarie University

\section{ENDNOTES}

${ }^{1}$ Anna Copeland, 'Public space: A rights-based approach', Youth Studies Australia, vol 23, no 3, 2004, pp40-45; Neile Robinson, 'Rights of passage', Youth Studies Australia, December 1999, vol 18, no 4, p22; Rob White, 'Sanitary cities: How designers banish the young and the poor', Architecture Australia, May 1996, pp5256; Chris Grant, 'Banning the banning notice', Alternative Law Journal, vol 25, no 1, 2000, pp32-44.

${ }^{2}$ Rob White, 'Forbidden city: Young people and public space', Arena Magazine, February-March 1995, pp34-37; Rob White, 'No-go in the fortress city: Young people, inequality and space', Urban Policy and Research, vol 14, no 1, p41.

${ }^{3}$ R.M. Vanderbeck and J.H. Johnson, “"That's the only place where you can hang out": Urban young people and the space of the mall', Urban Geography, vol 21, no 1, 2000, pp5-25.

${ }^{4}$ William Severini Kowinski, The Malling of America: An Inside Look at the Great Consumer Paradise, William Murrow, New York, 1985, p36. See also, George H., Lewis, 'Community through exclusion and illusion: The creation of social worlds in an American shopping mall', Journal of Popular Culture, vol 24, no 2, Fall 1990, pp121-136; K.H. Anthony, 'The shopping mall: A teenage hangout', Adolescence, vol 20, 1985, pp307-312. 
${ }^{5}$ On the cultural importance of the mall to American life, see, Hugh Matthews, Mark Taylor, Barry Percy-Smith and Melanie Limb, 'The unacceptable "flaneur": The shopping mall as a teenage hangout', Childhood: A Global Journal of Child Research, vol 7, no 3, August 2000, pp279-94.

${ }^{6}$ Records are stored in the Department of Modern History, Macquarie University. Throughout this paper they are referred to as Oral History Record (OHR), followed by the chronologically ordered number of the record and the date range within which they were posted on the survey site.

${ }^{7}$ Top Ryde, Warringah Mall and Miranda Fair were all were classified as 'regional centres', and all opened earlier.

${ }^{8}$ For a discussion of memories embedded in American retail environments, see, Matthew Bailey, 'Memory, Place and the Mall: George Romero on Post-War Consumer Culture', Studies in Popular Culture, vol 35, no 1, Fall 2013.

${ }^{9}$ Mark Crinson, 'Urban memory: an introduction', in Mark Crinson (ed) Urban Memory: History and Amnesia in the Modern City, Routledge, London and New York, 2005, pxiii.

${ }^{10}$ Aldo Rossi, The Architecture of the City, M.I.T. Press, Cambridge, 1984, p131.

${ }^{11}$ Mark Crinson, 'Urban memory: an introduction', pxv; Reuben Rose-Redwood, Derek Alderman, Maoz Azaryahu, 'Collective memory and the politics of urban space: an introduction', GeoJournal, no 73, 2008, p161.

${ }^{12}$ Frank Mort, 'Cityscapes: Consumption, masculinities and the mapping of London since 1950', Urban Studies, vol 35, no 5-6, 1998, pp893.

${ }^{13}$ Peter Spearritt, 'Suburban Cathedrals: The Rise of the Drive-In Shopping Centre', in Graeme Davison, Tony Dingle and Seamus O'Hanlon (eds), The Cream Brick Frontier: Histories of Australian Suburbia, Monash Publications in History, Clayton, 1995, pp98-99; Beverley Kingston, Basket, Bag and Trolley: A History of Shopping in Australia, Oxford University Press, Melbourne, 1994, p97; Graeme Davison with Sheryl Yelland, Car Wars: How the Car Won Our Hearts and Conquered Our Cities, Allen \& Unwin, Crows Nest, 2004, p107.

${ }^{14}$ Coles Myer Archive, SLV, MS13468, GRACS012, 69, 'Grace Bros. Parramatta Store History', July 1980; Nicholas Brash, The Model Store 1885 - 1985, Griffin Press, Adelaide, 1985, pp269-71; Inside Retailing, no 277, 27 June 1977, p6; Peter Spearritt, Sydney's Century: A History, UNSW Press, Sydney, 1999, p214.

${ }^{15} \mathrm{~F}$. A. Larcombe, Change and Challenge: A History of the Municipality of Canterbury, NSW, Canterbury Municipal Council, Canterbury, 1979, p360.

${ }^{16}$ Retail Trader, vol 47, no 4, November 1965, p10.

${ }^{17}$ F. A. Larcombe, Change and Challenge: A History of the Municipality of Canterbury, NSW, Canterbury Municipal Council, Canterbury, 1979, p176; Joan Lawrence, Brian Madden and Lesley Muir, A Pictorial History of Canterbury Bankstown, Kingsclear Books, Alexandria, 1999, p87.

${ }^{18}$ Canterbury City Council (Campsie) Library, Local Studies Collection, Roselands File, Laura Ferguson, 'Whatever Happened to the Raindrop Fountain: The History and Development of Roselands Shopping Centre', unpublished essay, p8.

${ }^{19}$ Retail Trader, vol 44, no 3, October 1962, p6.

${ }^{20}$ Retail Trader, vol 46, no 11, June 1965, pp4-5.

${ }^{21}$ ibid.

${ }^{22}$ Canterbury City Council (Campsie) Library, Local Studies Collection, Roselands File, Grace Bros. promotional brochure, 'Explore Roselands', c1965.

${ }^{23}$ Lindsay Barrett, 'Roselands, or everything under one roof', UTS Review, vol 4, no 2, 1998, p124.

${ }^{24}$ Robert Askin quoted in Sydney Morning Herald, October 12 1965, cited in Lindsay Barrett, 'Roselands, or everything under one roof', UTS Review, vol 4, no 2, 1998, p124. For pictures of the event and the crows crammed on the middle and upper levels, see, Coles Myer Archive, SLV, MS13468, GRACS012, 3458, 'Roselands from Store and Centre, Opening Day, Scrapbook', Roselands Interior, c1965. 
${ }^{25}$ Coles Myer Archive, SLV, MS13468, GRACS012, 58, Press Release, 'Roselands is a Building Triumph - says Mr E. A. Watts', 1965.

${ }^{26}$ Retail Trader, vol 46, no 11, June 1965, pp4-5.

${ }^{27}$ Sydney Morning Herald, 12 October 1965, quoted in Lindsay Barrett, 'Roselands, or everything under one roof', UTS Review, vol 4, no 2, 1998, p125.

${ }^{28}$ Barrett, 'Roselands', pp126-7.

${ }^{29}$ Terrence W. Beed, 'The Growth of Suburban Retailing in Sydney: A Preliminary Study of Some Factors Affecting the Form and Function of Suburban Shopping Centres', PhD thesis, University of Sydney, 1964, pp58-59.

${ }^{30}$ Sun Herald, 18 September 1965, p49.

${ }^{31}$ Bankstown Canterbury Torch, 6 October 1965.

${ }^{32}$ Maire-Louise, OHR no 33, 21 January 2007-27 January 2007; January, OHR no 36, 21 January 2007-27 January 2007; Margaret, OHR no 44, 21 January 2007-27 January 2007; Jenny, OHR no 45, 21 January 2007-27 January 2007; Robyn, OHR no 47, 21 January 2007-27 January 2007; Judith, OHR no 66, 11 February-11 March 2007; Meredith, OHR no 71, 11 February-11 March 2007.

${ }^{33}$ Bankstown Canterbury Torch, 20 October 1965, p27.

${ }^{34}$ ibid.

${ }^{35}$ Bankstown Canterbury Torch, 6 October 1965, p15; Daily Mirror, 11 October 1965, quoted in Barrett, op cit, p124.

${ }^{36}$ See Davison on the decline in such facilities over time: Graeme Davison, 'From the Market to the Mall', Background Report, Victorian Retail Policy Review, Department of Planning and Community Development, December 2006, p21.

${ }^{37}$ Victor Gruen, 'The Sad Story of Shopping Centres', Town and Country Planning, no 46, 1978, pp350-52.

${ }^{38}$ For the extensive community facilities promised by Myer in a proposed development at Bass Hill, see Torch, 3 April 1958, p3; Torch, 16 November 1961, p1. Sutherland Council had hoped for an auditorium in Miranda Fair, but settled for a large restaurant that could be hired for organised functions instead. See Sutherland Shire Council, Special General Committee Meeting, Minute no 161, 7 May 1962.

${ }^{39}$ The Retail Trader, vol 44, no 3, October 1962, p6.

${ }^{40}$ Steve Bedwell, Suburban Icons: A Celebration of the Everyday, Australian Broadcasting Corporation Sydney, 1992, p107.

${ }^{41}$ Canterbury City Council (Campsie) Library, Local Studies Collection, Roselands File, Grace Bros. promotional brochure, 'Explore Roselands', c1965.

${ }^{42}$ Lorne, personal communication, 3 October 2006.

${ }^{43}$ Canterbury City Council (Campsie) Library, Local Studies Collection, Roselands File, Grace Bros. promotional brochure, 'Explore Roselands', c1965.

${ }^{44}$ Canterbury City Council Records, 65 / 5766, 'Town Clerk's Report', 7 December 1965.

${ }^{45}$ George H. Lewis, 'Community through exclusion and illusion: The creation of social worlds in an American shopping mall', Journal of Popular Culture, vol 24, no 2, 1990, pp122-25.

${ }^{46}$ Patricia, OHR, no 76, 8 January 2008-23 February 2008.

${ }^{47}$ Ray, OHR, no 55, 28 January 2007-3 February 2007.

${ }^{48}$ Stefania, OHR, no 87, 8 January 2008-23 February 2008.

${ }^{49}$ Shonagh, OHR, no 32, 21 January 2007-27 January 2007.

${ }^{50}$ Michelle Arrow, Friday on Our Minds: Popular Culture in Australia Since 1945, UNSW Press, Sydney, 2009, pp44-65.

${ }^{51}$ Ken, personal communication, 4 December 2006.

52 Robert, OHR 11, 14 January 2007-20 January 2007.

${ }^{53}$ ibid.

${ }^{54}$ Pauline, personal communication, 20 April 2006.

55 'Ronnie in near riot', Go-Set, 29 January 1969, p9.

${ }^{56}$ Arrow, Friday on Our Minds, p66.

${ }^{57}$ On this dynamic, see ibid. 
${ }^{58}$ That young people can see malls as providing otherwise unavailable experiences, see, R.M. Vanderbeck and J.H. Johnson, "“That's the only place where you can hang out": Urban young people and the space of the mall', Urban Geography, vol 21, no 1, 2000, pp18-19.

${ }^{59}$ Ken, personal communication, 4 December 2006.

${ }^{60}$ Robert, OHR 11, 14 January 2007-20 January 2007.

${ }^{61}$ Retail Trader, December 1963, pp29-30.

${ }^{62}$ Lorne, personal communication, 3 October 2006. On the 'rock' $n$ 'roll generation', jukeboxes and Greek café's, see Leonard Janiszewski and Effi Alexakis, 'Selling an American Dream: Australia's Greek Café,' in Stephen Gregory (ed), Shop Till You Drop: Essays on Consuming and Dying in Australia, Southern Highlands Publishers, Sydney, 2008, p49.

${ }^{63}$ Robert, OHR 11, 14 January 2007-20 January 2007.

${ }^{64}$ On Sharps' clothing and their attitudes towards mods, see Seamus O'Hanlon, "'Where All the Action is, Man": Youth Culture in Melbourne in the 1960s', in Seamus O'Hanlon and Tanja Luckins (eds), Go! Melbourne in the Sixties, Circa, Melbourne, 2005, p54. That hippies were seen as 'effeminate "long-haired poofters"'; see Robert Wolfgramm, 'City in the Self: Melbourne (1968-70) as Seen from the Margins', in O'Hanlon and Luckins, Go!, p32.

${ }^{65}$ Lorne, personal communication, 3 March 2007.

${ }^{66}$ R.M. Vanderbeck and J.H. Johnson, "“That's the only place where you can hang out": Urban young people and the space of the mall', Urban Geography, vol 21, no 1, 2000, p6.

${ }^{67}$ Canterbury Council records index, 'Roselands Shopping Centre', no 2, April 1968, $68 / 1763$.

${ }^{68}$ Brent, personal communication, 17 January 2007.

${ }^{69}$ Ann Game and Rosemary Pringle, Gender at Work, George Allen \& Unwin, Sydney, 1983 p63; for similar trends internationally see Ian Alexander and John A. Dawson, 'Employment in retailing: A case study of employment in suburban shopping centres', Geoforum, vol 10, no 4, 1979, p408.

${ }^{70}$ W. J. Hudson, '1951-72', in F.K. Crowley (ed), A New History of Australia, William Heinemann Melbourne, 1977, p541.

${ }^{71}$ On the baby-boomers coming to employable age, see Garry Wotherspoon, City of the Plain: History of a Gay Sub-Culture, Hale \& Iremonger, Sydney, 1991, p140. On youth retail employment, see Retail Trader, vol 45, no 5, December 1963, pp29-30. On links between youth consumption and employment, see Arrow, Friday on Our Minds, pp49, 59.

${ }^{72}$ Robert, OHR 11, 14 January 2007-20 January 2007.

${ }^{73}$ Lorne, personal communication, 3 October 2006.

${ }^{74}$ Ken, personal communication, 4 December 2006; Lorne, personal communication, 3 October 2006.

${ }^{75}$ Pauline, personal communication, 20 April 202006.

${ }^{76}$ For a plot synopsis and review see 'Elvira Madigan', The Internet Movie Database, http:/ / www.imdb.com/title/tt0061620/plotsummary, and Bosley Crowther, 'Film festival: The landscape of love: 'Elvira Madigan' tells a bittersweet tale', New York Times, 30 September 1967, p26.

${ }^{77}$ Wotherspoon, City of the Plain, p135.

${ }^{78}$ Pauline, personal communication, 20 April 202006.

${ }^{79}$ P.D. Yeomans, 'Address to the Golden Jubilee Convention of the Real Estate Institute of New South Wales', Retail Trader, vol 42, no 7, February 1961, pp38, 42; Peter Spearritt, 'The Commercialisation of Public Space', in Patrick Troy (ed), Equity, Environment, Efficiency: Ethics and Economics in Urban Australia, Melbourne University Press, Carlton South, 2000, p93. For international literature on malls designed to manipulate consumers and encourage expenditure, see M. Gottdiener, 'Recapturing the Center: A Semiotic Analysis of Shopping Malls', in M. Gottdiener and A. Lagopoulos (eds), The City and the Sign: An Introduction to Urban Semiotics, 
Columbia University Press, New York, 1986, pp202-218; J. Goss, 'The "magic of the mall": An analysis of form, function, and meaning in the contemporary retail built environment', Annals of the Association of American Geographers, vol 83, 1993, pp1848 .

${ }^{80}$ This was a stated aim according to Brash, see Nicholas Brash, The Model Store 18851985, Griffin Press, Adelaide, 1985, pp275-76. Similarly, Myer in Melbourne planned to encircle that city with regional shopping centres in the 1960s. See Kim Humphery, Shelf life: Supermarkets and the Changing Cultures of Consumption, Cambridge University Press, Cambridge, Melbourne, 1998, p116.

${ }^{81}$ R.M. Vanderbeck and J.H. Johnson, "'That's the only place where you can hang out": Urban young people and the space of the mall', Urban Geography, vol 21, no 1, 2000, p20. See also, C. Katz, 'Disintegrating Developments: Global Economic Restructuring and the Eroding Ecologies of Youth', in T. Skelton and G. Valentine (eds), Cool Places: Geographies of Youth Cultures, Routledge, London, 1998, pp130144. 